\title{
Implementasi Algoritma Apriori Untuk Menentukan Strategi Promosi STIE-Graha Karya Muara Bulian
}

\author{
$\underline{\text { Azwar Anas }}$ \\ Program Studi Manajemen, STIE - Graha Karya Muara Bulian \\ Jl. Gajah Mada Muara Bulian-Indonesia \\ E-Mail: azwarzayn@gmail.com
}

\begin{abstract}
The purpose of this study is to determine the STIE-GK Muara Bulian promotion strategy. The author uses a priori algorithm to analyze the data of new students of STIE-GK Muara Bulian in the academic year 2018/2019. A priori algorithm was chosen because of its ability to analyze data that appears simultaneously and repeatedly and data that has accumulated a long time, so it is necessary to use data mining, to gain knowledge. The data that I use is the data of new students STIE-GK Muara Bulian randomly as many as 100. The research method that I use is to manually calculate data then a trial of the Weka data mining software is conducted. The results of this study indicate, partially Vocational High School and TKJ majors are the most contributors to new students with a confidence level of $13 \%$. The SMK and ADM majors are the second largest contributor to new students with a confidence level of $10 \%$. The management study program comes from the TKJ major with a confidence level of $7 \%$. The accounting study program comes from the TKJ major with a confidence level of $5 \%$.
\end{abstract}

Keywords: algorithm, a priori, data mining, promotion.

\begin{abstract}
Abstrak
Tujuan dari penelitian ini adalah untuk mengimplementasikan algoritma apriori untuk mendapatkan gambaran terhadap data mahasiswa baru STIE-GK Muara Bulian. Penulis menggunakan algoritma apriori untuk menganalisis data mahasiswa baru STIE-GK Muara Bulian tahun akademik 2018/2019. Algoritma apriori dipilih karena kemampuannya dalam menganalisis data yang muncul secara bersamaan dan berulang dan data yang telah menumpuk lama, sehingga perlu kiranya digunakan penambangan data, untuk mendapatkan pengetahuan. Data yang penulis gunakan adalah data mahasiswa baru STIE-GK Muara Bulian secara random sebanyak 100 orang. Metode penelitian yang penulis gunakan adalah dengan menghitung data menggunakan algoritma apriori kemudian dilakukan uji coba terhadap software data mining Weka. Adapun hasil penelitian ini menunjukkan, secara parsial Variabel SMK dan jurusan TKJ adalah penyumbang mahasiswa baru terbanyak dengan tingkat confidence mencapai 13\%. Variabel SMK dan jurusan ADM adalah penyumbang mahasiswa baru terbanyak kedua dengan tingkat confidence mencapai $10 \%$. Program studi manajemen berasal dari jurusan TKJ dengan tingkat confidence mencapai $7 \%$. Progam studi akuntansi berasal dari jurusan TKJ dengan tingkat confidence mencapai 5\%. Maka strategi yang digunakan untuk promosi mahasiswa baru tahun berikutnya adalah dengan meningkatkan intensitas di sekolah SMK pada jurusan TKJ.
\end{abstract}

Kata kunci: algoritma, apriori, data mining, promosi.

\section{Pendahuluan}

Indonesia merupakan negara dengan jumlah penduduk yang besar. Berdasarkan data dari Badan Pusat Statistik (BPS) per tahun 2018 mencapai 267,7 juta jiwa. Besarnya jumlah penduduk tersebut akan berdampak pada daya tampung berbagai kebutuhan seperti lapangan pekerjaan, akses kesehatan hingga pendidikan. Pemerintah dengan segala upaya dan kebijakannya terus berinovasi untuk memenuhi kebutuhan dasar tersebut.

UUD 1945 telah mengamanahkan kepada kita semua dalam upaya mencerdaskan kehidupan bangsa. Bagi masyarakat yang memiliki kemampuan finansial terbuka peluang untuk mendirikan PTS. Tentu saja dengan segala aturan yang telah ditetapkan. Pemerintah tentu sangat terbantu ketika PTS mampu memberikan akses pendidikan secara bedampingan dengan PTN milik pemerintah. Perbandingan jumlah PTN dan PTS di Indonesia saat ini adalah 370 PTN berbanding 4.043 PTS. Jika kita lihat dari jumlahnya maka ada sekitar 11 kali lipat jumlah PTN jika dibandingkan dengan PTS. Ini berarti peranan PTS di Indonesia sangatlah besar. 
Data mining merupakan bidang dari beberapa bidang kelmuan yang menyatukan teknik dari pembelajaran mesin, pengenalan pola statistic, database, dan visualisasi untuk penanganan permasalahan pengambilan informasi dari database yang besar[1]. Data mining adalah suatu istilah yang digunakan untuk menguraikan penemuan pengetahuan di dalam database. Data mining adalah proses yang menggunakan teknik statistik, matematika, kecerdasan buatan, dan machine learning untuk mengekstrasksi dan mengidentifikasi informasi yang bermanfaat dan pengetahuan yang terkait dari berbagai database besar[2].

Penerapan algoritma apriori telah banyak digunakan sebelumnya untuk mendapatkan informasi berharga dari sejumlah frekuensi data. Berikut beberapa penerapan algoritma apriori yang telah dilakukan :

1. Algoritma Asosiasi untuk Mendapatkan Pola Mata Kuliah Pilihan STIE-GK Muara Bulian[3]. Dalam penelitian ini fokus pembahasannya adalah pada pengolahan data mata kuliah pilihan di STIE-GK Muara Bulian dengan menggunakan algoritma asosiasi sehingga mendapatkan pola dari mata kuliah pilihan tersebut.

2. Implementasi Data Mining Pada Penjualan Tiket Pesawat Menggunakan Algoritma Apriori (Studi Kasus: Jumbo Travel Medan)[4]. Makalah ini fokus menggunakan algoritma apriori dalam menganalisa penjualan tiket pesawat terbang yang biasa dijual secara bersamaan sesuai dengan banyaknya konsumen.

3. Implementasi Data Mining Algoritma Apriori pada Sistem Persediaan Alat-alat Kesehatan[5]. Fokus penelitian ini adalah pada penggunaan algoritma apriori dalam sisem persediaan alat-alat kesehatan, hal ini didasarkan pada penjualan sebelumnya.

4. Pengembangan Sistem Rekomendasi Penelusuran Buku dengan Penggalian Association Rule Menggunakan Algoritma Apriori (Studi Kasus Badan Perpustakaan dan Kearsipan Provinsi Jawa Timur)[6]. Pada penelitian ini metode yang digunakan dalam identifikasi pola yang dimaksud adalah association rule dengan algoritma apriori. Metode dan algoritma ini menghasilkan transaksitransaksi peminjaman buku dengan strong association (keterkaitan yang kuat) antar buku dalam transaksi yang digunakan sebagai rekomendasi peminjaman buku yang membantu pengguna mendapatkan rekomendasi buku lain ketika pengguna melihat rincian dari buku yang dipilih atau hendak dipinjam. Dari hasil uji coba pada penelitian ini, ditemukan bahwa semakin besar minimum support (minsup) dan minimum confidence (minconf), semakin sedikit waktu yang dibutuhkan untuk menghasilkan rekomendasi serta semakin sedikit rekomendasi yang diberikan, namun rekomendasi yang diberikan berasal dari transaksi yang sering muncul.

5. Penerapan Data Mining Untuk Klasifikasi Prediksi Penyakit ISPA (Infeksi Saluran Pernapasan Akut) Dengan Algoritma Decision Tree (Id3). Penelitian ini fokus pada pemanfaatan data mining menggunakan algoritma Decision Tree dalam pengelompokan dan perkiraan penyakit ISPA[7].

Berdasarkan data Forlap Dikti tahun akademik 2017/2018 jumlah PTS di Indonesia berjumlah 4.186. Banyaknya jumlah PTS telah menciptakan persaingan bagi setiap pengelola untuk menampung calon mahasiswa sebanyak-banyaknya. Karena bagaimanapun sumber keuangan operasional PTS berasal dari mahasiswanya. Semakin banyak mahasiswanya maka semakin sehat keuangan operasional PTS tersebut. STIE-Graha Karya Muara Bulian merupakan PTS di bidang ilmu ekonomi yang berada di Kabupaten Batanghari - Jambi. Pesaing terkuat dari PTS ini dalam menerima mahasiswa barunya adalah IAI Nusantara Batanghari yang berjarak hanya sekitar $2 \mathrm{Km}$. Persaingan ini membuat STIE-GK Muara Bulian semakin gencar melakukan promosi ke sekolah-sekolah potensial sebagai calon mahasiswa baru. Persoalan yang ada adalah, tidak adanya pemetaan wilayah potensial calon mahasiswa baru. Hal ini disebabkan oleh tidak adanya analisis terhadap hal tersebut berdasarkan data-data mahasiswa baru tahuntahun sebelumnya. Penambangan data ini diharapkan mampu menentukan strategi yang tepat sasaran dalam melakukan promosi bagi STIE-GK Muara Bulian.

Dalam penelitian ini penulis akan fokus pada strategi promosi STIE-GK Muara Bulian kepada calon mahasiswa baru. Jumlah data yang dianalisis adalah 100 data mahassiwa baru tahun akademik 2018/2019, hal ini sesuai dengan jumlah total mahasiswa baru yang ada. Itemset-itemset tersebut akan diolah dengan menggunakan Algoritma Apriori untuk mendapat kecenderungan indikator yang muncul secara bersamaan. Sedangkan software yang digunakan untuk menampilkan hasilnya adalah Weka.

\section{Metodologi}

Algoritma apriori termasuk jenis aturan asosiasi pada data mining. Aturan yang menyatakan asosiasi antara beberapa atribut sering disebut affinity analysis atau market basket analysis. Analisis asosiasi atau 
association rule mining adalah teknik data mining untuk menemukan aturan suatu kombinasi item. Salah satu tahap analisis asosiasi yang menarik perhatian banyak peneliti untuk menghasilkan algoritma yang efisien adalah analisis pola frequensi tinggi(frequent pattern mining). Penting tidaknya suatu asosiasi dapat diketahui dengan dua tolak ukur, yaitu : support dan confidence. Support (nilai penunjang) adalah persentase kombinasi item tersebut dalam database, sedangkan confidence (nilai kepastian) adalah kuatnya hubungan antar-item dalam aturan asosiasi[8]. Analisis asosiasi atau association rule mining adalah teknik data mining untuk menemukan aturan asosiasi antara suatu kombinasi item [9].

Algoritma apriori adalah algoritma pengambilan data dengan aturan asosiatif (Association rule) untuk menentukan hubungan asosiatif suatu kombinasi item. Association Rule yang dimaksud dilakukan melalui mekanisme penghitungan support dan confidence dari suatu hubungan item. Sebuah rule asosiasi dikatakan interesting jika nilai support adalah lebih besar dari minimum support dan juga nilai confidence adalah lebih besar dari minimum confidence. Algoritma apriori ini akan cocok untuk diterapkan bila terdapat beberapa hubungan item yang ingin dianalisa [10].

Dalam melakukan sebuah penelitian, tentu harus berdasarkan metode penelitian yang benar sehingga dapat mempermudah jalannya penelitian tersebut. Metode penelitian merupakan kerangka kerja dalam melakukan penelitian. Dengan mengikuti kerangka kerja tersebut maka penelitian yang dilakukan akan berjalan dengan sistematis dan memberikan hasil yang baik.

Pada bagian ini akan diuraikan kerangka penelitian, kerangka ini merupakan langkah-langkah yang akan dilakukan dalam penyelesaian masalah yang akan dibahas. Langkahnya diuraikan seperti gambar berikut ini :

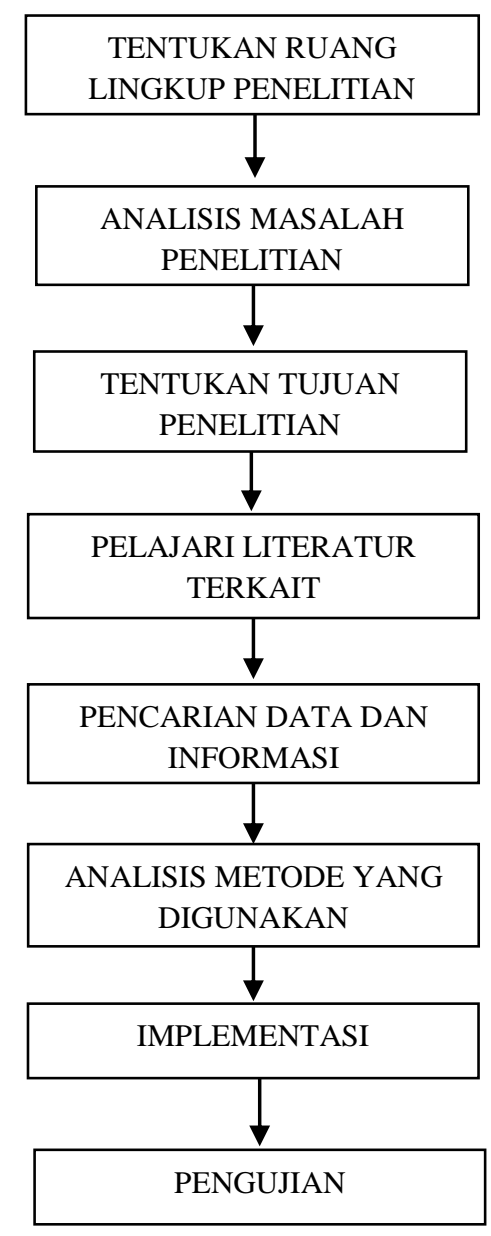

Gambar 1. Kerangka Kerja Penelitian 


\subsection{Analisis Asosiasi dengan Algoritma Apriori}

Dalam penelitian ini, penulis melakukan analisis terhadap 100 data mahasiswa baru tahun akademik 2018/2019 STIE-GK Muara Bulian. Penulis melakukan analisis terhadap data kecamatan, sekolah, jurusan dan program studi pilihan.

Aturan asosiasi biasanya dinyatakan dalam bentuk :

$\{\mathrm{PMY}, \mathrm{SMA}, \mathrm{IPA}\} \rightarrow$ Manajemen $\}$ support $=40 \%$, confidence $=50 \%\}$

Artinya 50\% dari indikator pilihan program studi Manajemen berasal dari Kecamatan Pemayung, sekolah SMA dan jurusan IPA. Sementara $40 \%$ dari seluruh program studi Manajemen yang ada memuat semua item tersebut.

\subsection{Menentukan Variabel}

Data yang akan diolah dalam menentukan strategi promosi ini adalah berdasarkan indikator data mahasiswa baru. Adapun variabel-variabel data mahasiswa baru yang akan diolah adalah:

1. Mahasiswa

2. Kecamatan

3. Sekolah

4. Jurusan

5. Program Studi

Dari variabel-variabel di atas, setiap indikator akan dibagi kedalam beberapa kelompok berdasarkan jenis indikator yang sama, hal ini dilakukan agar proses analisa data dapat dilakukan dengan mudah menggunakan algoritma apriori.

\subsection{Analisis Frekuensi Tinggi}

Tahapan ini mencari kombinasi item yang memenuhi syarat minimum dari nilai support dalam database. Nilai support sebuah item diperoleh dengan rumus berikut :

Support $(A)=\frac{\text { lumi ai transaksims ngandun } g A}{\text { I umi an transaksi }}$

Sedangkan nilai support dari 2 item diperoleh dari rumus berikut :

Support $(A, B)=P(A \cap B)$

Support $(A, B)=\frac{\sum J \text { umi an transaksims ngandung } A \text { dan } B}{\Gamma . J \text { umi an transaksi }}$

\subsection{Melakukan Proses}

Berdasarkan variabel-variabel mahasiswa baru di atas, maka format data dapat dilihat pada tabel berikut ini :

Tabel 1. Data Mahasiswa Baru

\begin{tabular}{ccccc}
\hline MAHASISWA & KECAMATAN & SEKOLAH & JURUSAN & PROGRAM STUDI \\
\hline 1 & Mbl & SMA & Ipa & Manajemen \\
2 & Mbl & SMK & Adm & Manajemen \\
3 & Msu & MA & Ips & Manajemen \\
4 & Mtb & SMA & Ips & Akuntansi \\
5 & Mbl & SMK & Tkj & Akuntansi \\
6 & Pmy & MA & Ipa & Manajemen \\
7 & Btn & SMK & Msn & Akuntansi
\end{tabular}




\begin{tabular}{ccccc}
8 & Msi & SMA & Ipa & Akuntansi \\
9 & Msm & SMA & Ips & Akuntansi \\
10 & Msu & MA & Ipa & Manajemen \\
11 & Msi & MA & Ips & Akuntansi \\
12 & Mbl & SMK & Tkj & Manajemen \\
13 & Mbl & SMK & Adm & Akuntansi \\
14 & Bjb & SMK & Tkj & Manajemen \\
15 & Bjb & SMA & Ipa & Akuntansi \\
16 & Msi & SMA & Ips & Manajemen \\
17 & Pmy & SMK & Adm & Akuntansi \\
18 & Mbl & SMA & Ipa & Manajemen \\
19 & Mbl & SMK & Adm & Manajemen \\
20 & Msu & MA & Ipa & Manajemen \\
\hline
\end{tabular}

Setelah data diperoleh, selanjutnya adalah mengelompokkan mahasiswa berdasarkan data yang sama sebagaimana tabel berikut.

Data transaksional di atas lalu direpresentasikan dalam bentuk seperti terlihat pada tabel berikut ini :

Tabel 2. Representasi Data Variabel Mahasiswa Baru

\begin{tabular}{clllll}
\hline Mhs & Variabel & 7 & Msn & 14 & Tkj \\
\hline 1 & Mbl & 7 & Akuntansi & 14 & Manajemen \\
1 & SMA & 8 & Msi & 15 & Bjb \\
1 & IPA & 8 & SMA & 15 & SMA \\
1 & Manajemen & 8 & IPA & 15 & IPA \\
2 & Mbl & 8 & Akuntansi & 15 & Akuntansi \\
2 & SMK & 9 & Msm & 16 & Msi \\
2 & Adm & 9 & IPA & 16 & SMA \\
2 & Manajemen & 9 & IPS & 16 & IPS \\
3 & Msu & 9 & Akuntansi & 16 & Manajemen \\
3 & MA & 10 & Msu & 17 & Pmy \\
3 & IPS & 10 & MA & 17 & SMK \\
3 & Manajemen & 10 & IPA & 17 & Adm \\
4 & Mtb & 10 & Manajemen & 17 & Akuntansi \\
4 & SMA & 11 & Msi & 18 & Mbl \\
4 & IPS & 11 & MA & 18 & SMA \\
4 & Akuntansi & 11 & IPS & 18 & IPA \\
5 & Mbl & 11 & Akuntansi & 18 & Manajemen \\
5 & SMK & 12 & Mbl & 19 & Mbl \\
5 & Tkj & 12 & SMK & 19 & SMK \\
5 & Akuntansi & 12 & Tkj & 19 & Adm \\
6 & Pmy & 12 & Manajemen & 19 & Manajemen \\
6 & SMA & 13 & Mbl & 20 & Msu \\
6 & IPA & 13 & SMK & 20 & MA \\
6 & Manajemen & 13 & Adm & 20 & IPA \\
7 & Btn & 13 & Akuntansi & 20 & Manajemen \\
7 & SMK & 14 & Bjb & & \\
& & 14 & SMK & &
\end{tabular}

Pada pengujian ini, penulis menetapkan nilai minimum support sebesar $0,1 \%$ dan minimum confidence sebesar $0,9 \%$. Sehingga data yang akan diproses oleh software Weka hanyalah rule-rule yang memenuhi kriteria di atas. 


\section{Hasil dan Pembahasan}

\subsection{Pembentukan Aturan Asosiasi}

Setelah semua pola frekuensi tinggi ditemukan, barulah dicari aturan asosiasi yang memenuhi syarat minimum untuk confidence dengan menghitung confidence aturan asosiasi $\mathrm{A} \rightarrow \mathrm{B}$. Aturan asosiasi yang terbentuk berdasarkan minimum support dan minimum confidence dapat dilihat pada tabel 4 berikut.

Tabel 3. Aturan Asosiasi yang Terbentuk

\begin{tabular}{|c|c|c|}
\hline Aturan & Support & Confidence \\
\hline Jika mahasiswa baru dari Jurusan Tkj maka sekolah SMK & $10 \%$ & $13 \%$ \\
\hline Jika mahasiswa baru dari jurusan Adm maka sekolah SMK & $10 \%$ & $11 \%$ \\
\hline $\begin{array}{l}\text { Jika mahasiswa baru dari jurusan Tkj dan memilih program studi Manajemen } \\
\text { maka berasal dari SMK }\end{array}$ & $10 \%$ & $7 \%$ \\
\hline $\begin{array}{l}\text { Jika mahasiswa baru dari jurusan Adm dan memilih program studi Manajemen } \\
\text { maka berasal dari SMK }\end{array}$ & $10 \%$ & $5 \%$ \\
\hline $\begin{array}{l}\text { Jika mahaisswa baru dari jurusan Tkj dan memilih program studi Akuntansi } \\
\text { maka berasal dari SMK }\end{array}$ & $10 \%$ & $5 \%$ \\
\hline
\end{tabular}

\subsection{Hasil Pengujian pada Software}

Pengujian terhadap hasil analisa, sangat penting dilakukan untuk menentukan dan memastikan apakah hasil analisa tersebut benar atau tidak. Software yang penulis gunakan dalam pengujian ini adalah Weka. Tahapan dalam pengujian pada Weka adalah sebagai berikut:

a. Aktifkan software Weka sehingga tampil gambar berikut.

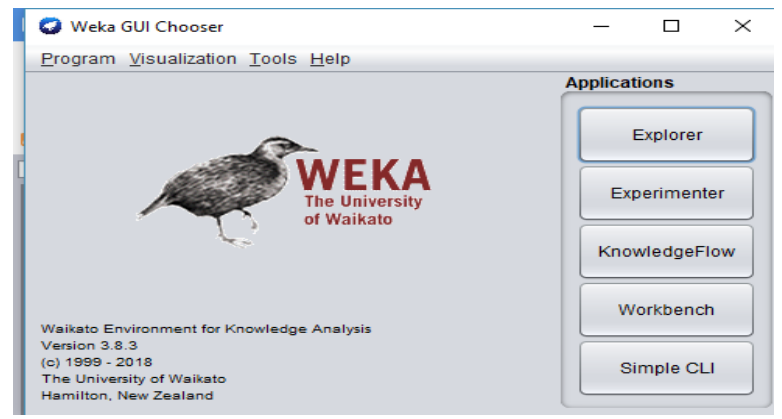

Gambar 2. Area Kerja pada Weka

b. Setelah jendela Weka terbuka, klik menu Explorer, klik menu Preprocess, Open File, cari database seperti gambar berikut.

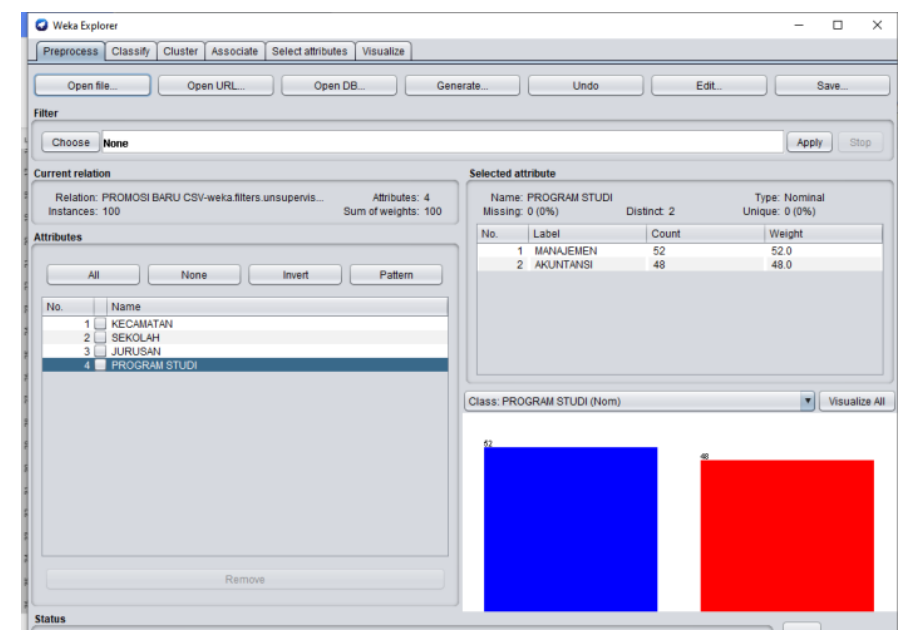

Gambar 3. Proses Pemanggilan Data 
c. Langkah berikutnya adalah klik menu Associate, pilih Apriori lalu klik Start untuk memunculkan rule yang terbentuk, sebagaimana gambar berikut;

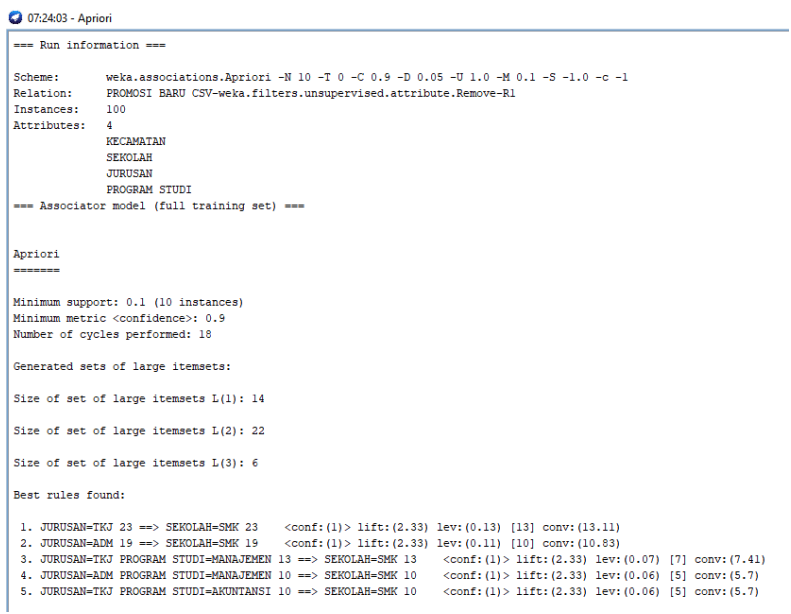

Gambar 4. Rule yang Terbentuk

\section{Kesimpulan}

Dari pembahasan di atas, maka ada kesimpulan yang diperoleh adalah bahwa variabel SMK dan jurusan TKJ adalah penyumbang mahasiswa baru terbanyak dengan tingkat confidence mencapai 13\%, Variabel SMK dan jurusan ADM adalah penyumbang mahasiswa baru terbanyak kedua dengan tingkat confidence mencapai 10\%, Program studi manajemen berasal dari jurusan TKJ dengan tingkat confidence mencapai 7\% dan Progam studi akuntansi berasal dari jurusan TKJ dengan tingkat confidence mencapai 5\%. Pihak berwenang kampus STIE-GK Muara Bulian, agar memperhatikan sekolah tujuan promosi berikutnya dan meningkatkan promosi ke sekolah sekolah yang yang masih minim.

\section{Daftar Rujukan}

[1]. Anas A, Darma B. Analisis Dosen Favorit STIE-GK Muara Bulian Menggunakan Algoritma Apriori. 2019;13(2).

[2]. Anas A. Algorithm Apriori Use for a Consumer Behavior in. Sains dan Inform. 2015;1:45-59.

[3]. Anas A, Darma B. ALGORITMA ASOSIASI UNTUK MENDAPATKAN POLA MATA KULIAH PILIHAN STIE-GK MUARA BULIAN. 2019;6(1):1-12.

[4]. Wardah Z. Implementasi Data Mining Pada Penjualan Tiket Pesawat Menggunakan Algoritma Apriori (Studi Kasus : PT. Pesona Ceria Travel). 2017;2(2):31-39.

[5]. Tampubolon K, Saragih H, Reza B, Epicentrum K, Asosiasi A, Apriori A. Implementasi Data Mining Algoritma Apriori Pada Sistem Persediaan Alat-Alat Kesehatan. 2013:93-106.

[6]. Wandi N, Hendrawan RA, Mukhlason A. Pengembangan Sistem Rekomendasi Penelusuran Buku dengan Penggalian Association Rule Menggunakan Algoritma Apriori. J Tek ITS. 2012;1:1-5.

[7]. Aline Embun Pramadhani TS. PENERAPAN DATA MINING UNTUK KLASIFIKASI PREDIKSI PENYAKIT ISPA (Infeksi Saluran Pernapasan Akut) DENGAN ALGORITMA DECISION TREE (ID3). J Sarj Tek Inform Vol. 2014;2.

[8]. Pane DK. Implementasi Data Mining Pada Penjualan Produk Elektronik Dengan Algoritma Apriori ( Studi Kasus : Kreditplus ). Pelita Inform Budi Darma. 2013; valume : I:25-29. doi:23019425

[9]. Sugianti D. Peminjaman Buku Di Perpustakaan Stmik Widya Pratama. 2015;(1):22-28.

[10]. Yanto R, Khoiriah R. Implementasi Data Mining dengan Metode Algoritma Apriori dalam Menentukan Pola Pembelian Obat. Creat Inf Technol J. 2015;2(2):102. doi:10.24076/citec.2015v2i2.41 